\title{
An Estimate of Chlorine-Induced Volatilities of Actinides in the Rocky Flats Plant Fluidized Bed Incinerator
}

Oscar H. Krikorian

Bartley B. Ebbinghaus

Martyn G. Adamson

December 1993

This is an informal report intended primarily for internal or limited external distribution. The opinions and conclusions stated are those of the author and may or may not be those of the Laboratory.

Work performed under the auspices of the U.S. Department of Energy by the Lawrence Livermore National Laboratory under Contract W-7405-ENG-48. 


\section{DISCLAIMER}

This documeat was prepared as an account of work sponsored by an agency of the United States Government. Neither the United States Government nor the University of California nor any of their employees, makes any warranty, express or implied, or assumes any legal liability or responsibility for the accuracy, completeness, or usefulness of any information, apparatus, product, or process disclosed, or represents that its use would not infringe privately owned rights. Reference herein to any specific commercial products, process, or service by trade name, trademark, manufacturer, or otherwise, does not necessarily constitute or imply its endorsement, recommendation, or favoring by the United States Government or the University of Califormia. The views and opinions of authors expressed herein do not necessarily state or refect those of the United States Government or the University of California, and shall not be used for advertising or product endorsement purposes.

This report has been reproduced directly from the best available copy.

Available to DOE and DOE contractors from the Office of Scientific and Technical Information

P.O. Box 62, Oak Ridge, TN 37831

Prices available from (615) 576.8401, FTS 626.8401

Available to the public from the

National Technical Information Service

US. Department of Commerce 5285 Port Royal Rd. Springfield, VA 22161 


\title{
An Estimate of Chlorine-Induced Volatilities of Actinides in the Rocky Flats Plant Fluidized Bed Incinerator
}

\author{
Ciscar H. Krikorian \\ Bartley B. Ebbinghaus \\ Martyn G. Adamson \\ University of California \\ Lawrence Livermore National Laboratory \\ Livermore, CA 94551
}

\begin{abstract}
An estimate is made of the effects of chlorine on volatilization of actinides during combustion in the RFP Fluidized Bed Incinerator. The volatile species are assumed to be $\mathrm{UO}_{2} \mathrm{Cl}_{2}(\mathrm{~g}), \mathrm{PuO}_{2} \mathrm{Cl}_{2}(\mathrm{~g})$, and $\mathrm{AmO}_{2} \mathrm{Cl}_{2}(\mathrm{~g})$. Available thermodynamic data are used to calculate vapor pressures of $\mathrm{UO}_{2} \mathrm{Cl}_{2}(\mathrm{~g})$. Recent thermodynamic data on $\mathrm{PuO}_{2}(\mathrm{OH})_{2}(g)$ volatilities are used to provide predictive thermodynamic data for $\mathrm{PuO}_{2} \mathrm{Cl}_{2}(\mathrm{~g})$. The $\mathrm{AmO}_{2} \mathrm{Cl}_{2}(\mathrm{~g})$ vapor pressure is assumed to be the same as the $\mathrm{PuO}_{2} \mathrm{Cl}_{2}(\mathrm{~g})$ vapor pressure but reduced by the $\mathrm{AmO}_{2}(\mathrm{~s})$ mole fraction in $\mathrm{PuO}_{2}(\mathrm{~s})$. Assuming that chlorine in the waste produces an $\mathrm{HCl}(\mathrm{g})$ pressure of $10^{-2} \mathrm{~atm}$ in the combustion chamber, the actinide volatilization rates in the offgas are calculated to be of $1.5 \mathrm{~g} / \mathrm{y} \mathrm{U}, 22 \mu \mathrm{g} / \mathrm{y} \mathrm{Pu}$, and $4.4 \mathrm{ng} / \mathrm{y} \mathrm{Am}$.
\end{abstract}




\section{Introduction}

The purpose of this report is to provide an estimate of the chlorine-induced volatilities of actinides in the Rocky Flats Plant Fluidized Bed Incinerator.

The volatilization of actinides that occurs during combustion of mixed wastes in incinerators and other thermal oxidation processors leads primarily to condensation of the actinides on fine flyash particulates $(<1 \mu \mathrm{m})$ or to formation of actinide-containing aerosols in the offgas. The flyash contains actinide oxides formed in the combustion process, and some small fraction of this flyash is in the $<1 \mu \mathrm{m}$ size range. Particulates in this size range are of concern because they are difficult to filter out and may result in air emissions from the process. HEPA filters are effective at removing $\sim 99.97 \%$ of these particulates. It is important to understand the volatilization contribution of actinides to the fine particulates in order to determine the extent of concentration of actinides on these particulates.

We have previously made measurements of $\mathrm{U}, \mathrm{Pu}$, and Am volatilities in the presence of steam and oxygen to evaluate the extent of gaseous actinide oxide and oxyhydroxide species that form under combustion conditions [1]. We were able to quantitatively establish the $U$ species volatilities, assuming equilibrium conditions prevail in the combustion process. For Pu and Am species, the volatilities were found to be very low, and we were only able to establish upper limits for the volatilities. The data are still very useful for evaluating volatility limits in thermal oxidation processors. We have made some further measurements on $\mathrm{Pu}$ volatilities (work supported by DOE Defense Programs), which will be discussed in this report.

When chlorine or fluorine are present in the combustion, actinide volatilization as oxychloride or oxyfluoride species is expected in addition to the oxide and oxyhydroxide species. We are interested here in estimating the $\mathrm{Cl}$-induced volatilities. Thermodynamic measurements are available for $\mathrm{UO}_{2} \mathrm{Cl}_{2}(\mathrm{~g})$ [2], although the volatilizing species was only assumed and not identified in the study. We assume the identification to be correct for our purposes here, and that $\mathrm{UO}_{2} \mathrm{Cl}_{2}(\mathrm{~g})$ is the only important uranium oxychloride species. There are no thermodynamic data for $\mathrm{Pu}$ and Am oxychloride gases. Predictions are made herein of thermodynamic data for the Pu and Am oxychloride species based on bond energy comparisons between $U$ species and Pu species.

\section{Recent Pu Volatility Measurements}

Since our last report [1], further transpiration measurements have been made at higher temperatures on ${ }^{238} \mathrm{PuO}_{2}$ volatilities in the presence of $\mathrm{O}_{2}(\mathrm{~g})$ and $\mathrm{H}_{2} \mathrm{O}(\mathrm{g})$. This work was done under DOE Defense Programs funding, and has not yet been written up. Please refer to our previous report [1] for experimental 
details. We give here the results for the highest temperature runs at $1475 \mathrm{~K}$, which indicate the presence of both $\mathrm{PuO}_{3}(\mathrm{~g})$ and $\mathrm{PuO}_{2}(\mathrm{OH})_{2}(\mathrm{~g})$. These runs were made without the silica glass wool filter in place in front of the collection tube. It appeared that the $\mathrm{PuO}_{2}$ sample had sintered sufficiently as to reduce dust carryover to below the volatility levels.

The transpiration data are summarized in Table 1. For runs 106, 107 and 111, which only had $\mathrm{O}_{2}(\mathrm{~g})$ present, we take $\mathrm{Pu}$ to be volatilized only as $\mathrm{PuO}_{3}(\mathrm{~g})$. The volatilization reaction and equilibrium constant are given by

$$
\begin{aligned}
\mathrm{PuO}_{2}(\mathrm{~s}) & +1 / 2 \mathrm{O}_{2}(\mathrm{~g})=\mathrm{PuO}_{3}(\mathrm{~g}), \\
\mathrm{K}_{1} & =\mathrm{p}\left(\mathrm{PuO}_{3}\right) / \mathrm{a}\left(\mathrm{PuO}_{2}\right) \mathrm{p}\left(\mathrm{O}_{2}\right)^{1 / 2},
\end{aligned}
$$

where the activity of $\mathrm{PuO}_{2}(\mathrm{~s})$ is unity. We find the average value of $\mathrm{K}_{1}$ at $1475 \mathrm{~K}$ to be $4.03 \times 10^{-11} \mathrm{~atm}^{1 / 2}$ for the three runs. For volatilization to $\mathrm{PuO}_{2}(\mathrm{OH})_{2}(\mathrm{~g})$, the reaction and equilibrium constant are given by

$$
\begin{array}{r}
\mathrm{PuO}_{2}(\mathrm{~s})+1 / 2 \mathrm{O}_{2}(\mathrm{~g})+\mathrm{H}_{2} \mathrm{O}(\mathrm{g})=\mathrm{PuO}_{2}(\mathrm{OH})_{2}(\mathrm{~g}), \\
\mathrm{K}_{2}=\mathrm{p}\left(\mathrm{PuO}_{2}(\mathrm{OH})_{2}\right) / \mathrm{a}\left(\mathrm{PuO}_{2}\right) \mathrm{p}\left(\mathrm{O}_{2}\right)^{1 / 2} \mathrm{p}\left(\mathrm{H}_{2} \mathrm{O}\right) .
\end{array}
$$

Values for $\mathrm{p}\left(\mathrm{PuO}_{2}(\mathrm{OH})_{2}\right)$ are obtained from runs 105, 108, 109 and 110, by deducting $\mathrm{p}\left(\mathrm{PuO}_{3}\right)$ values (calculated using $\left.\mathrm{K}_{1}\right)$ from the experimental $\mathrm{p}(\mathrm{Pu}$ total). The $K_{2}$ values are then calculated (see Table 2). The average value of $K_{2}$ at 1475 $\mathrm{K}$ for the four experiments is $5.77 \times 10^{-10}$. The dependence of $\mathrm{Pu}$ volatility on $\mathrm{H}_{2} \mathrm{O}$ pressure is illustrated in Fig. 1 where $p(\mathrm{Pu}$ total $) / \mathrm{p}\left(\mathrm{O}_{2}\right)^{1 / 2}$ is plotted as a function of $p\left(\mathrm{H}_{2} \mathrm{O}\right)$ for the experimental data. The solid line represents the $K_{1}$ and $K_{2}$ values derived herein. The variation of $\mathrm{Pu}$ volatility with $\mathrm{H}_{2} \mathrm{O}$ pressure is consistent with formation of $\mathrm{PuO}_{2}(\mathrm{OH})_{2}(\mathrm{~g})$.

Based upon the $\mathrm{K}_{1}$ value at $1475 \mathrm{~K}$ obtained herein and using auxiliary thermodynamic data given earlier [1], we calculate a $\Delta \mathrm{H}^{\circ}{ }_{\mathrm{r}, 298}$ for reaction (1) of $500.03 \pm 5.0 \mathrm{~kJ} / \mathrm{mol}$, and a $\Delta \mathrm{H}^{\circ}{ }_{\mathrm{f}, 298}$ for $\mathrm{PuO}_{3}(\mathrm{~g})$ of $-555.77 \pm 5.5 \mathrm{~kJ} / \mathrm{mol}$. Similarly, based upon the $\mathrm{K}_{2}$ value at $1475 \mathrm{~K}$ obtained herein, we obtain a $\Delta \mathrm{H}^{\circ}{ }_{r, 298}$ of $337.97 \pm 9.0 \mathrm{~kJ} / \mathrm{mol}$ for reaction (2) and a $\Delta \mathrm{H}^{\circ}{ }_{\mathrm{f} .298}$ for $\mathrm{PuO}_{2}(\mathrm{OH})_{2}(\mathrm{~g})$ of $-959.66 \pm 9.5 \mathrm{~kJ} / \mathrm{mol}$. The uncertainties are taken only from the experimental scatter of the most recent data. If previous data is taken into account, the uncertainties are considerably larger. 
Table 1. Transpiration data for $\mathrm{Pu}$ volatility from ${ }^{238} \mathrm{PuO}_{2}(\mathrm{~s})$. Measurements were all made at $1475 \mathrm{~K}$.

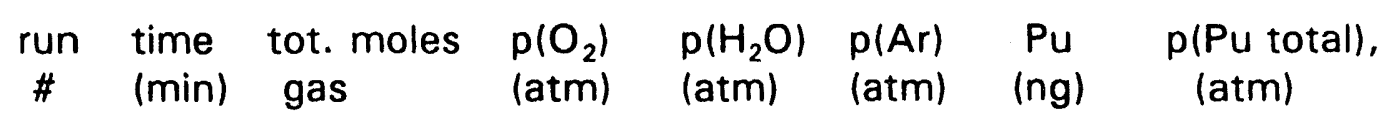

\begin{tabular}{llllllll}
\hline 105 & 120 & 0.638 & 0.389 & 0.611 & -- & 19.2 & $1.27 \times 10^{-10}$ \\
106 & 120 & 0.248 & 1.000 & -- & -- & 2.48 & $4.20 \times 10^{-11}$ \\
107 & 240 & 0.124 & 1.000 & -- & -- & 1.59 & $5.39 \times 10^{-11}$ \\
108 & 120 & 0.758 & 0.0654 & 0.699 & 0.235 & 21.5 & $1.19 \times 10^{-10}$ \\
109 & 120 & 0.345 & 0.144 & 0.338 & 0.518 & 8.03 & $9.79 \times 10^{-11}$ \\
110 & 120 & 0.266 & 0.186 & 0.144 & 0.670 & 4.21 & $6.64 \times 10^{-11}$ \\
111 & 360 & 0.186 & 1.000 & -- & -- & 1.11 & $2.51 \times 10^{-11}$
\end{tabular}

Table 2. Determination of $\mathrm{p}\left(\mathrm{PuO}_{2}(\mathrm{OH})_{2}\right)$ by difference, and calculation of $\mathrm{K}_{\mathrm{eq}}$ for the reaction $\mathrm{PuO}_{2}(\mathrm{~s})+1 / 2 \mathrm{O}_{2}(\mathrm{~g})+\mathrm{H}_{2} \mathrm{O}=\mathrm{PuO}_{2}(\mathrm{OH})_{2}(\mathrm{~g})$.

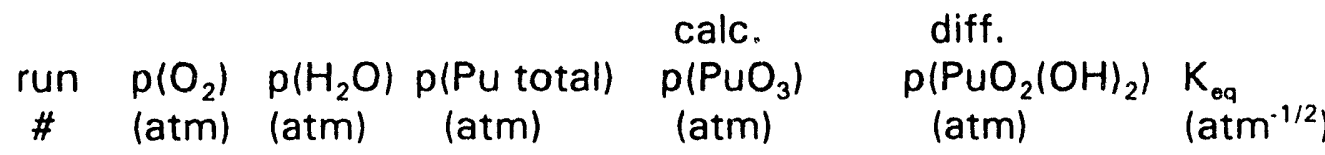

$\begin{array}{lllllll}105 & 0.389 & 0.611 & 1.26 \times 10^{-10} & 2.51 \times 10^{-11} & 1.01 \times 10^{-10} & 2.66 \times 10^{-10} \\ 108 & 0.065 & 0.699 & 1.19 \times 10^{-10} & 1.03 \times 10^{-11} & 1.09 \times 10^{-10} & 6.08 \times 10^{-10} \\ 109 & 0.144 & 0.338 & 9.79 \times 10^{-11} & 1.53 \times 10^{-11} & 8.26 \times 10^{-11} & 6.44 \times 10^{-10} \\ 110 & 0.186 & 0.144 & 6.64 \times 10^{-11} & 1.74 \times 10^{-11} & 4.90 \times 10^{-11} & 7.90 \times 10^{-10}\end{array}$

ave. $\quad 5.77 \times 10^{-10}$ 

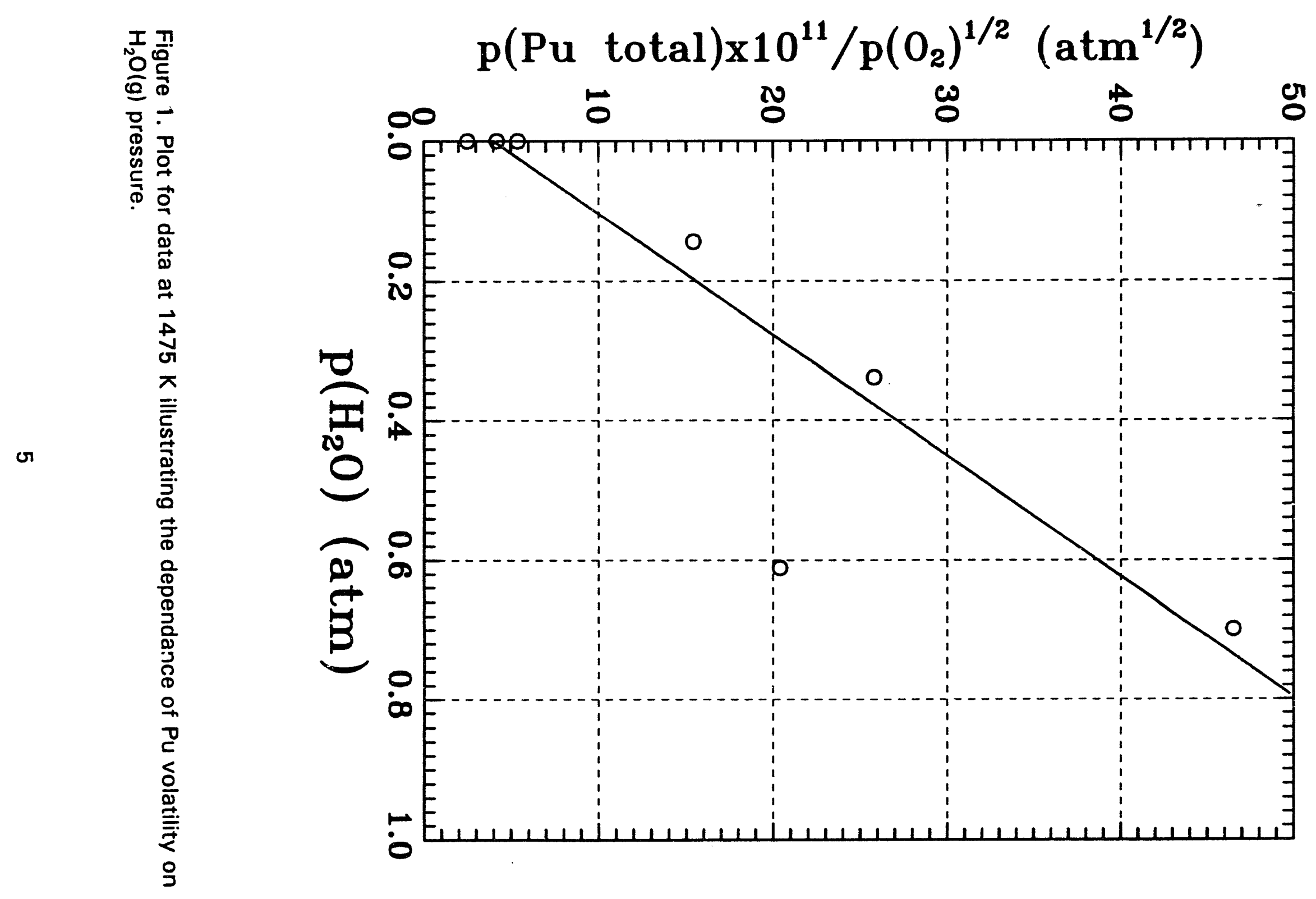


\section{Prediction of Thermodynamic Values for $\mathrm{PuO}_{2} \mathrm{Cl}_{2}(\mathrm{~g})$}

Consider the reactions:

$$
\begin{aligned}
& \mathrm{UO}_{2}(\mathrm{OH})_{2}(\mathrm{~g})=\mathrm{UO}_{2}(\mathrm{~g})+2 \mathrm{OH}(\mathrm{g}),{\Delta \mathrm{H}^{\circ}{ }_{r, 298}=763.97 \mathrm{~kJ} / \mathrm{mol}} \mathrm{UO}_{2} \mathrm{Cl}_{2}(\mathrm{~g})=\mathrm{UO}_{2}(\mathrm{~g})+2 \mathrm{Cl}(\mathrm{g}), \Delta \mathrm{H}_{r, 298}^{\circ}=745.50 \mathrm{~kJ} / \mathrm{mol} \\
& \mathrm{PuO}_{2}(\mathrm{OH})_{2}(\mathrm{~g})=\mathrm{PuO}_{2}(\mathrm{~g})+2 \mathrm{OH}(\mathrm{g}), \Delta \mathrm{H}_{r, 298}^{\circ}=624.96 \mathrm{~kJ} / \mathrm{mol} \\
& \mathrm{PuO}_{2} \mathrm{Cl}_{2}(\mathrm{~g})=\mathrm{PuO}_{2}(\mathrm{~g})+2 \mathrm{Cl}(\mathrm{g}), \Delta \mathrm{H}_{r, 298}^{\circ}=609.85 \mathrm{~kJ} / \mathrm{mol}
\end{aligned}
$$

Thermodynamic data are known for all of the species in these reactions except for $\mathrm{PuO}_{2} \mathrm{Cl}_{2}(\mathrm{~g})$. Enthalpy changes $\left(\Delta \mathrm{H}^{\circ}{ }_{r, 298}\right)$ for the reactions represent bond energies for breaking of two bonds, i.e., in reaction (3) two $\mathrm{U}-\mathrm{OH}$ bonds are broken, in reaction (4) two $\mathrm{U}-\mathrm{Cl}$ bonds are broken, and so forth. We make the approximation that the ratio of bond energies of reaction (3) to reaction (4) is the same as the ratio of bond energies of reaction (5) to reaction (6). This then gives a value for the enthalpy change for reaction (6), which allows us to calculate a value for the enthalpy of formation of $\mathrm{PuO}_{2} \mathrm{Cl}_{2}(\mathrm{~g})$. Free energy function data will need to be estimated using the molecular constant method to complete the required data for $\mathrm{PuO}_{2} \mathrm{Cl}_{2}(\mathrm{~g})$.

The sources of thermodynamic data that are needed for the reactions above are as follows. The $\Delta \mathrm{H}^{\circ}{ }_{4,298}$ value for $\mathrm{UO}_{2}(\mathrm{OH})_{2}(\mathrm{~g})$ is given in our previous report [1], and for $\mathrm{PuO}_{2}(\mathrm{OH})_{2}(\mathrm{~g})$ is given above. The $\Delta \mathrm{H}^{\circ}{ }_{f, 298}$ values for $\mathrm{OH}(\mathrm{g})$ and $\mathrm{Cl}(\mathrm{g})$ are from the JANAF tables [3]. The $\Delta \mathrm{H}^{\circ}{ }_{\mathrm{f}, 298}$ value for $\mathrm{UO}_{2}(\mathrm{~g})$ is given by Green [4]. For $\mathrm{UO}_{2} \mathrm{Cl}_{2}(\mathrm{~g})$, a $\Delta \mathrm{H}^{\circ}{ }_{\mathrm{f}, 298}$ value of $-969.20 \pm 2.0 \mathrm{~kJ} / \mathrm{mol}$ is obtained from a third law analysis of volatility data by Cordfunke and Prins [2]. The free energy functions for $\mathrm{UO}_{2} \mathrm{Cl}_{2}(\mathrm{~g})$ are calculated from estimated molecular constants (see Table 3). For $\mathrm{PuO}_{2}(\mathrm{~g})$, a $\Delta \mathrm{H}^{\circ}{ }_{\mathrm{f}, 298}$ value of $-413.36 \pm 12.5 \mathrm{~kJ} / \mathrm{mol}$ was obtained from a third law analysis of transpiration measurements by Pardue and Keller [5] of $\mathrm{PuO}_{2}(\mathrm{~s})$ volatility under 1 atm $\mathrm{O}_{2}$ pressure. Free energy function data for $\mathrm{PuO}_{2}(\mathrm{~g})$ were calculated from molecular constant data given by Green [4]. The $\Delta H^{\circ}{ }_{1,298}$ values used for the uranium and plutonium oxides, oxyhydroxides, and oxychlorides are summarized in Table 4.

Utilizing the $\Delta \mathrm{H}^{\circ}{ }_{\mathrm{f}, 298}$ data, we obtain the $\Delta \mathrm{H}^{\circ}{ }_{\mathrm{r}, 298}$ values shown in equations (3) to (5), and taking the ratio of bond energies for reaction (3) to (4) to be the same as for reaction (5) to (6), the $\Delta H^{{ }^{\circ}}{ }_{r, 298}$ value shown in equation (6) is obtained. With this value of $\Delta \mathrm{H}^{\circ}{ }_{r, 298}$ for equation (6), and using the known 
Table 3. Estimated molecular constants and calculated standard entropies, heat capacities, and free energy functions for $\mathrm{UO}_{2} \mathrm{Cl}_{2}(\mathrm{~g})$ and $\mathrm{PuO}_{2} \mathrm{Cl}_{2}(\mathrm{~g})$.

Molecular constants for $\mathrm{UO}_{2} \mathrm{Cl}_{2}(\mathrm{~g}): \mathrm{MW}=340.934 \mathrm{~g} / \mathrm{mol}$, degeneracy of ground state $=1$, structure is $C_{2 v}$ with sigma $=2, U-O$ bond length $=0.2538$ $\mathrm{nm}, \mathrm{U}-\mathrm{Cl}$ bond length $=0.180 \mathrm{~nm}$, vibrational frequencies (in $\mathrm{cm}^{-1}$ ): 776.1 , $765.43,348,323,92,91,225.2,225.2$, and 70 .

Molecular constants for $\mathrm{PuO}_{2} \mathrm{Cl}_{2}(\mathrm{~g}): \mathrm{MW}=341.95 \mathrm{~g} / \mathrm{mol}$, degeneracy of ground state $=9\left(\mathrm{f}^{2}-{ }^{3} \mathrm{H}_{4}\right.$ ground state), structure is $\mathrm{C}_{2 v}$ with sigma $=2, \mathrm{Pu}-\mathrm{O}$ bond length $=0.2538 \mathrm{~nm}, \mathrm{Pu}-\mathrm{Cl}$ bond length $=0.180 \mathrm{~nm}$, vibrational frequencies (in $\mathrm{cm}^{-1}$ ): $776.1,765.43,348,323,92,91,225.2,225.2$, and 70 .

$$
\begin{aligned}
& C_{p}=A_{1}+A_{2} \times 10^{-3} T+A_{3} \times 10^{-6} T^{2}+A_{4} \times 10^{-9} T^{3}+A_{5} \times 10^{-12} T^{4}, T=298-2300 K \\
& \begin{array}{llllll}
S^{\circ}{ }_{298} & A_{1} & A_{2} & A_{3} & A_{4} & A_{5}
\end{array} \\
& \mathrm{~J} / \mathrm{mol}-\mathrm{K} \quad \mathrm{J} / \mathrm{mol}-\mathrm{K} \quad \mathrm{J} / \mathrm{mol}^{2} \mathrm{~K}^{2} \quad \mathrm{~J} / \mathrm{mol}^{-\mathrm{K}^{3}} \mathrm{~J} / \mathrm{mol}^{4} \mathrm{~K}^{4} \mathrm{~J} / \mathrm{mol} \mathrm{K}^{5}
\end{aligned}
$$

$\begin{array}{lllllll}\mathrm{UO}_{2} \mathrm{Cl}_{2}(\mathrm{~g}) & 373.36 & 72.847 & 91.215 & -91.6491 & 40.3818 & -6.49615 \\ \mathrm{PuO}_{2} \mathrm{Cl}_{2}(\mathrm{~g}) & 391.66 & 72.847 & 91.215 & -91.6491 & 40.3818 & -6.49615\end{array}$

$\begin{array}{lll} & -\left(\mathrm{G}^{\circ} \mathrm{T}-\mathrm{H}^{\circ}{ }_{298}\right) / \mathrm{T} \\ \mathrm{T} & \mathrm{UO}_{2} \mathrm{Cl}_{2}(\mathrm{~g}) & \mathrm{PuO}_{2} \mathrm{Cl}_{2}(\mathrm{~g}) \\ (\mathrm{K}) & (\mathrm{J} / \mathrm{mol}-\mathrm{K}) & (\mathrm{J} / \mathrm{mol}-\mathrm{K})\end{array}$

\begin{tabular}{ccc}
\hline 800 & 408.633 & 426.939 \\
900 & 416.361 & 434.667 \\
1000 & 423.718 & 442.023 \\
1100 & 430.702 & 449.007 \\
1200 & 437.329 & 455.634 \\
1300 & 443.620 & 461.925 \\
1400 & 449.600 & 467.905 \\
1500 & 455.293 & 473.598 \\
1600 & 460.720 & 479.026 \\
\hline
\end{tabular}


Table 4. Summary of $\Delta H^{\circ}{ }_{1.298}$ values for uranium and plutonium oxides, oxyhydroxides, and oxychlorides.

\begin{tabular}{lll} 
species & $\begin{array}{l}\Delta \mathrm{H}^{\circ}, 298 \\
(\mathrm{~kJ} / \mathrm{mol})\end{array}$ \\
\hline & & \\
$\mathrm{UO}$ & \\
$\mathrm{UO}_{3}(\mathrm{~g})$ & $-466.30 \pm 5.0$ & from ref. [4] \\
$\mathrm{UO}_{2}(\mathrm{OH})_{2}(\mathrm{~g})$ & $-7151.61 \pm 7.5$ & from ref. [1] \\
$\mathrm{UO}_{2} \mathrm{Cl}_{2}(\mathrm{~g})$ & $-969.20 \pm 2.0$ & $3^{\text {rd }}$ law calc. \\
& & \\
$\mathrm{PuO}_{2}(\mathrm{~g})$ & $-413.36 \pm 12.5$ & $3^{\text {rd }}$ law calc. \\
$\mathrm{PuO}_{3}(\mathrm{~g})$ & $-555.77 \pm 5.5$ & $3^{\text {rd law calc. }}$ \\
$\mathrm{PuO}_{2}(\mathrm{OH})_{2}(\mathrm{~g})$ & $-959.66 \pm 9.5$ & $3^{\text {rd law calc. }}$ \\
$\mathrm{PuO}_{2} \mathrm{Cl}_{2}(\mathrm{~g})$ & -780.61 & estimated \\
& &
\end{tabular}


$\Delta \mathrm{H}^{\circ}{ }_{\mathrm{f}, 298}$ values for $\mathrm{PuO}_{2}(\mathrm{~g})$ and $\mathrm{Cl}(\mathrm{g})$ in equation $(6)$, a $\Delta \mathrm{H}^{\circ}{ }_{\mathrm{f}, 298}$ value of -780.61 $\mathrm{kJ} / \mathrm{mol}$ for $\mathrm{PuO}_{2} \mathrm{Cl}_{2}(\mathrm{~g})$ is obtained. To complete the thermodynamic data for $\mathrm{PuO}_{2} \mathrm{Cl}_{2}(\mathrm{~g})$, we have calculated free energy functions as shown in Table 3. The standard entropy and a heat capacity equation for both $\mathrm{PuO}_{2} \mathrm{Cl}_{2}(\mathrm{~g})$ and $\mathrm{UO}_{2} \mathrm{Cl}_{2}(\mathrm{~g})$ are also given in Table 3.

\section{Application to RFP Fluidized Bed Incinerator}

We now apply the thermodynamic data to estimate the $\mathrm{Cl}$-induced actinide volatilities in the RFP Fluidized Bed Incinerator. Combustion of chlorinated hydrocarbons produces $\mathrm{HCl}(\mathrm{g})$ as a combustion product. The $\mathrm{HCl}(\mathrm{g})$ further reacts with the $\mathrm{Na}_{2} \mathrm{CO}_{3}(\mathrm{~s})$ in the bed to form $\mathrm{NaCl}(\mathrm{s})$ and reduces the $\mathrm{HCl}(\mathrm{g})$ pressure to a very low level. The reaction is given by

$$
\mathrm{Na}_{2} \mathrm{CO}_{3}(\mathrm{~s})+2 \mathrm{HCl}(\mathrm{g})=2 \mathrm{NaCl}(\mathrm{s})+\mathrm{H}_{2} \mathrm{O}(\mathrm{g})+\mathrm{CO}_{2}(\mathrm{~g}) \text {. }
$$

Assuming equilibrium for the reaction, we calculate (see JANAF [3] for thermodynamic data) $K_{e q}=3.4 \times 10^{-7}$ for the reaction at $823 \mathrm{~K}$, and with $\mathrm{p}\left(\mathrm{H}_{2} \mathrm{O}\right)=$ $0.05 \mathrm{~atm}$ and $\mathrm{p}\left(\mathrm{CO}_{2}\right)=0.1 \mathrm{~atm}$, we find $\mathrm{p}(\mathrm{HCl})=3.40 \times 10^{-7} \mathrm{~atm}$. If however, $\mathrm{HCl}(\mathrm{g})$ does not fully equilibrate with $\mathrm{Na}_{2} \mathrm{CO}_{3}(\mathrm{~s})$, then higher $\mathrm{HCl}(\mathrm{g})$ pressures will be present and can enhance the volatilities of the actinides. We will assume higher $\mathrm{HCl}(\mathrm{g})$ levels to evaluate the effects on volatilities.

We also need to know the chemical forms of the actinide oxides that result from the combustion process. For uranium, we had previously [1] taken the form to be $\mathrm{Na}_{2} \mathrm{UO}_{4}(\mathrm{~s})$. This form had been taken on the assumption of thermodynamic equilibration which gives a very low $\mathrm{HCl}(\mathrm{g})$ pressure (see above). As $\mathrm{HCl}(\mathrm{g})$ pressures are increased, $\mathrm{Na}_{2} \mathrm{UO}_{4}$ will no longer be stable, but uranium will form $\mathrm{U}_{3} \mathrm{O}_{8}(\mathrm{~s})$. This is shown by the reaction,

$$
\begin{gathered}
\mathrm{Na}_{2} \mathrm{UO}_{4}(\mathrm{~s})+2 \mathrm{HCl}(\mathrm{g})=1 / 3 \mathrm{U}_{3} \mathrm{O}_{8}(\mathrm{~s})+2 \mathrm{NaCl}(\mathrm{s}) \\
+\mathrm{H}_{2} \mathrm{O}(\mathrm{g})+1 / 6 \mathrm{O}_{2}(\mathrm{~g})
\end{gathered}
$$

which we calculate (see refs. $[1,3]$ for sources of thermodynamic data) to have a $\mathrm{K}_{\text {eq }}$ of $1.53 \times 10^{7} \mathrm{~atm}^{.5 / 6}$ at $823 \mathrm{~K}$, and with $\mathrm{p}\left(\mathrm{H}_{2} \mathrm{O}\right)=0.05$ atm and $\mathrm{p}\left(\mathrm{O}_{2}\right)=0.10$ atm, the $\mathrm{HCl}(\mathrm{g})$ pressure is $4.7 \times 10^{-5} \mathrm{~atm}$. Thus, at pressures of $\mathrm{HCl}(\mathrm{g})$ greater than $4.7 \times 10^{-5}$ atm, $\mathrm{Na}_{2} \mathrm{UO}_{4}(\mathrm{~s})$ will no longer be stable but $\mathrm{U}_{3} \mathrm{O}_{8}(\mathrm{~s})$ will be the stable form. For plutonium, we take the stable form to be $\mathrm{PuO}_{2}(\mathrm{~s})$, and for americium, we take a $200 \mathrm{ppm}$ solid solution of $\mathrm{AmO}_{2}$ in $\mathrm{PuO}_{2}(\mathrm{~s})$.

Thermodynamic data are not available for americium oxychloride gaseous species. We will assume the species to be $\mathrm{AmO}_{2} \mathrm{Cl}_{2}(\mathrm{~g})$ and the free energy of vaporization of $\mathrm{AmO}_{2} \mathrm{Cl}_{2}(\mathrm{~g})$ from $\mathrm{AmO}_{2}(\mathrm{~s})$ to be the same as for $\mathrm{PuO}_{2} \mathrm{Cl}_{2}(\mathrm{~g})$ from $\mathrm{PuO}_{2}(\mathrm{~s})$. Further assuming $\mathrm{AmO}_{2}$ to be present as an ideal solution in $\mathrm{PuO}_{2}(\mathrm{~s})$, the 
$\mathrm{AmO}_{2} \mathrm{Cl}_{2}(\mathrm{~g})$ volatilities will be in proportion to the $\mathrm{PuO}_{2} \mathrm{Cl}_{2}(\mathrm{~g})$ volatilities according to the $\mathrm{AmO}_{2}$ content in $\mathrm{PuO}_{2}(\mathrm{~s})$. Making similar assumptions, we take the volatilities of $\mathrm{AmO}_{3}(\mathrm{~g})$ and $\mathrm{AmO}_{2}(\mathrm{OH})_{2}(\mathrm{~g})$ to be in proportion to $\mathrm{PuO}_{3}(\mathrm{~g})$ and $\mathrm{PuO}_{2}(\mathrm{OH})_{2}(\mathrm{~g})$ volatilities according to the $\mathrm{AmO}_{2}$ content in $\mathrm{PuO}_{2}(\mathrm{~s})$.

We now proceed to calculate the volatilities of the actinide oxide, actinide oxyhydroxide, and actinide oxychloride species under the RFP Fluidized Bed Incinerator conditions and summarize the results in Table 5. Four different conditions of $\mathrm{HCl}(\mathrm{g})$ pressures ranging from $10^{-4}$ to $10^{-1} \mathrm{~atm}$ are assumed for the calculations. Thermodynamic data for these calculations are from our previous report [1] for $\mathrm{UO}_{3}(\mathrm{~g})$ and $\mathrm{UO}_{2}(\mathrm{OH})_{2}(\mathrm{~g})$, for $\mathrm{UO}_{2} \mathrm{Cl}_{2}(\mathrm{~g})$ and all of the $\mathrm{Pu}$ species as discussed above, and for the Am species, according to the approximations indicated above. Auxiliary thermodynamic data are from our previous report [1] and from the JANAF tables [3]. The volatilization reactions are summarized as follows.

$$
\begin{aligned}
& 1 / 3 \mathrm{U}_{3} \mathrm{O}_{8}(\mathrm{~s})+1 / 6 \mathrm{O}_{2}(\mathrm{~g})=\mathrm{UO}_{3}(\mathrm{~g}) \text {, } \\
& 1 / 3 \mathrm{U}_{3} \mathrm{O}_{8}(\mathrm{~s})+1 / 6 \mathrm{O}_{2}(\mathrm{~g})+\mathrm{H}_{2} \mathrm{O}(\mathrm{g})=\mathrm{UO}_{2}(\mathrm{OH})_{2}(\mathrm{~g}) \text {, } \\
& 1 / 3 \mathrm{U}_{3} \mathrm{O}_{8}(\mathrm{~s})+1 / 6 \mathrm{O}_{2}(\mathrm{~g})+2 \mathrm{HCl}(\mathrm{g})=\mathrm{UO}_{2} \mathrm{Cl}_{2}(\mathrm{~g})+\mathrm{H}_{2} \mathrm{O}(\mathrm{g}) \text {, } \\
& \mathrm{PuO}_{2}(\mathrm{~s})+1 / 2 \mathrm{O}_{2}(\mathrm{~g})=\mathrm{PuO}_{3}(\mathrm{~g}) \text {, } \\
& \mathrm{PuO}_{2}(\mathrm{~s})+1 / 2 \mathrm{O}_{2}(\mathrm{~g})+\mathrm{H}_{2} \mathrm{O}(\mathrm{g})=\mathrm{PuO}_{2}(\mathrm{OH})_{2}(\mathrm{~g}) \text {, } \\
& \mathrm{PuO}_{2}(\mathrm{~s})+1 / 2 \mathrm{O}_{2}(\mathrm{~g})+2 \mathrm{HCl}(\mathrm{g})=\mathrm{PuO}_{2} \mathrm{Cl}_{2}(\mathrm{~g})+\mathrm{H}_{2} \mathrm{O}(\mathrm{g}) \text {, } \\
& \mathrm{AmO}_{2}\left(\mathrm{ss} \text { in } \mathrm{PuO}_{2}\right)+1 / 2 \mathrm{O}_{2}(\mathrm{~g})=\mathrm{AmO}_{3}(\mathrm{~g}) \text {, } \\
& \left.\mathrm{AmO}_{2} \text { (ss in } \mathrm{PuO}_{2}\right)+1 / 2 \mathrm{O}_{2}(\mathrm{~g})+\mathrm{H}_{2} \mathrm{O}(\mathrm{g})=\mathrm{AmO}_{2}(\mathrm{OH})_{2}(\mathrm{~g}) \text {, } \\
& A \mathrm{mO}_{2}\left(\mathrm{ss} \text { in } \mathrm{PuO}_{2}\right)+1 / 2 \mathrm{O}_{2}(\mathrm{~g})+2 \mathrm{HCl}(\mathrm{g})=\mathrm{AmO}_{2} \mathrm{Cl}_{2}(\mathrm{~g})+\mathrm{H}_{2} \mathrm{O}(\mathrm{g}) \text {. }
\end{aligned}
$$

We find that the actinide oxychloride species dominate over the oxide and oxyhydroxide species in all cases for the $\mathrm{HCl}(\mathrm{g})$ pressures that we have chosen. We will illustrate the annual amount of volatilized actinides evolved in the offgas for the case where $\mathrm{p}(\mathrm{HCl})$ is $10^{-2}$ atm for the RFP Fluidized Bed Incinerator. Taking the conditions given in Table 5 with an offgas flow rate of $40 \mathrm{kmol} / \mathrm{h}$ and an operational time of $6000 \mathrm{~h} / \mathrm{y}$, volatilization rates of $1.5 \mathrm{~g} / \mathrm{V} \mathrm{U}, 22 \mu \mathrm{g} / \mathrm{y} \mathrm{Pu}$, and 4.4 $\mathrm{ng} / \mathrm{y} \mathrm{Am}$ are obtained. These are very low values, and are reduced even further through the use of HEPA filters for removal of the actinide condensates on fine flyash particulates. 
Table 5. Calculated pressures in atm of actinide vapor species at $823 \mathrm{~K}$ as a function of $p(\mathrm{HCl})$ where $p\left(\mathrm{O}_{2}\right)$ and $p\left(\mathrm{CO}_{2}\right)$ are taken as $0.10 \mathrm{~atm}$ and $p\left(\mathrm{H}_{2} \mathrm{O}\right)$ is taken as 0.05 atm. $U$ is taken to be present as $U_{3} O_{8}(s), P u$ as $\mathrm{PuO}_{2}(s)$ and Am as 200 ppm $\mathrm{AmO}_{2}$ in $\mathrm{PuO}_{2}$ (s).

$\begin{array}{ccccc}\mathrm{p}(\mathrm{HCl}) & \begin{array}{c}1.0 \times 10^{-4} \\ (\mathrm{~atm})\end{array} & \begin{array}{c}1.0 \times 10^{-3} \\ \text { (atm) }\end{array} & \begin{array}{c}1.0 \times 10^{-2} \\ \text { (atm) }\end{array} & \begin{array}{l}0.10 \\ \text { (atm) }\end{array}\end{array}$

$\begin{array}{lllll}\mathrm{p}\left(\mathrm{UO}_{3}\right) & 1.8 \times 10^{-17} & 1.8 \times 10^{-17} & 1.8 \times 10^{-17} & 1.8 \times 10^{-17} \\ \mathrm{p}\left(\mathrm{UO}_{2}(\mathrm{OH})_{2}\right) & 5.8 \times 10^{-16} & 5.8 \times 10^{-16} & 5.8 \times 10^{-16} & 5.8 \times 10^{-16} \\ \mathrm{p}\left(\mathrm{UO}_{2} \mathrm{Cl}_{2}\right) & 2.6 \times 10^{-15} & 2.6 \times 10^{-13} & 2.6 \times 10^{-11} & 2.6 \times 10^{-9} \\ & & & & \\ \mathrm{p}\left(\mathrm{PuO}_{3}\right) & 4.5 \times 10^{-25} & 4.5 \times 10^{-25} & 4.5 \times 10^{-25} & 4.5 \times 10^{-25} \\ \mathrm{p}\left(\mathrm{PuO}_{2}\left(\mathrm{OH}_{2}\right)\right. & 5.4 \times 10^{-21} & 5.4 \times 10^{-21} & 5.4 \times 10^{-21} & 5.4 \times 10^{-21} \\ \mathrm{p}\left(\mathrm{PuO}_{2} \mathrm{Cl}_{2}\right) & 3.9 \times 10^{-20} & 3.9 \times 10^{-18} & 3.9 \times 10^{-16} & 3.9 \times 10^{-14} \\ & & & & \\ \mathrm{p}\left(\mathrm{AmO}_{3}\right) & 9.0 \times 10^{-29} & 9.0 \times 10^{-29} & 9.0 \times 10^{-29} & 9.0 \times 10^{-29} \\ \mathrm{p}\left(\mathrm{AmO}_{2}(\mathrm{OH})_{2}\right) & 1.1 \times 10^{-24} & 1.1 \times 10^{-24} & 1.1 \times 10^{-24} & 1.1 \times 10^{-24} \\ \mathrm{p}\left(\mathrm{AmO}_{2} \mathrm{Cl}_{2}\right) & 7.8 \times 10^{-24} & 7.8 \times 10^{-22} & 7.8 \times 10^{-20} & 7.8 \times 10^{-18}\end{array}$




\section{References}

1. O. H. Krikorian, B. B. Ebbinghaus, M. G. Adamson, A. S. Fontes, Jr., and D. L. Fleming, "Experimental Studies and Thermodynamic Modeling of Volatilities of Uranium, Plutonium, and Americium from Their Oxides and from Their Oxides Interacted with Ash," Lawrence Livermore National Laboratory Report, UCRL-ID-114774, September 15, 1993.

2. E. H. P. Cordfunke and G. Prins, "Equilibria Involving Volatile $\mathrm{UO}_{2} \mathrm{Cl}_{2}, " \mathrm{~J}$. Inorg. Nucl. Chem., 36, 1291-1293 (1974).

3. M. W. Chase, Jr., C. A. Davies, J. R. Downey, Jr., D. J. Frurip, R. A. McDonald, and A. N. Syverud, JANAF Thermochemical Tables, Third Edition, Parts I and II (J. Phys. Chem. Ref. Data, 14, 1985, Supplement No. 1), American Chemical Society and American Institute of Physics, New York, 1986.

4. D. W. Green, "Standard Enthalpies of Formation of Gaseous Thorium, Uranium, and Plutonium Oxides," Internat. J. Thermophys., 1, 61-71 (1980).

5. W. M. Pardue and D. L. Kelle, "Volatility of $\mathrm{PuO}_{2}$ in Nonreducing Atmospheres," J. Amer. Ceram. Soc., 47, 610-614 (1964). 

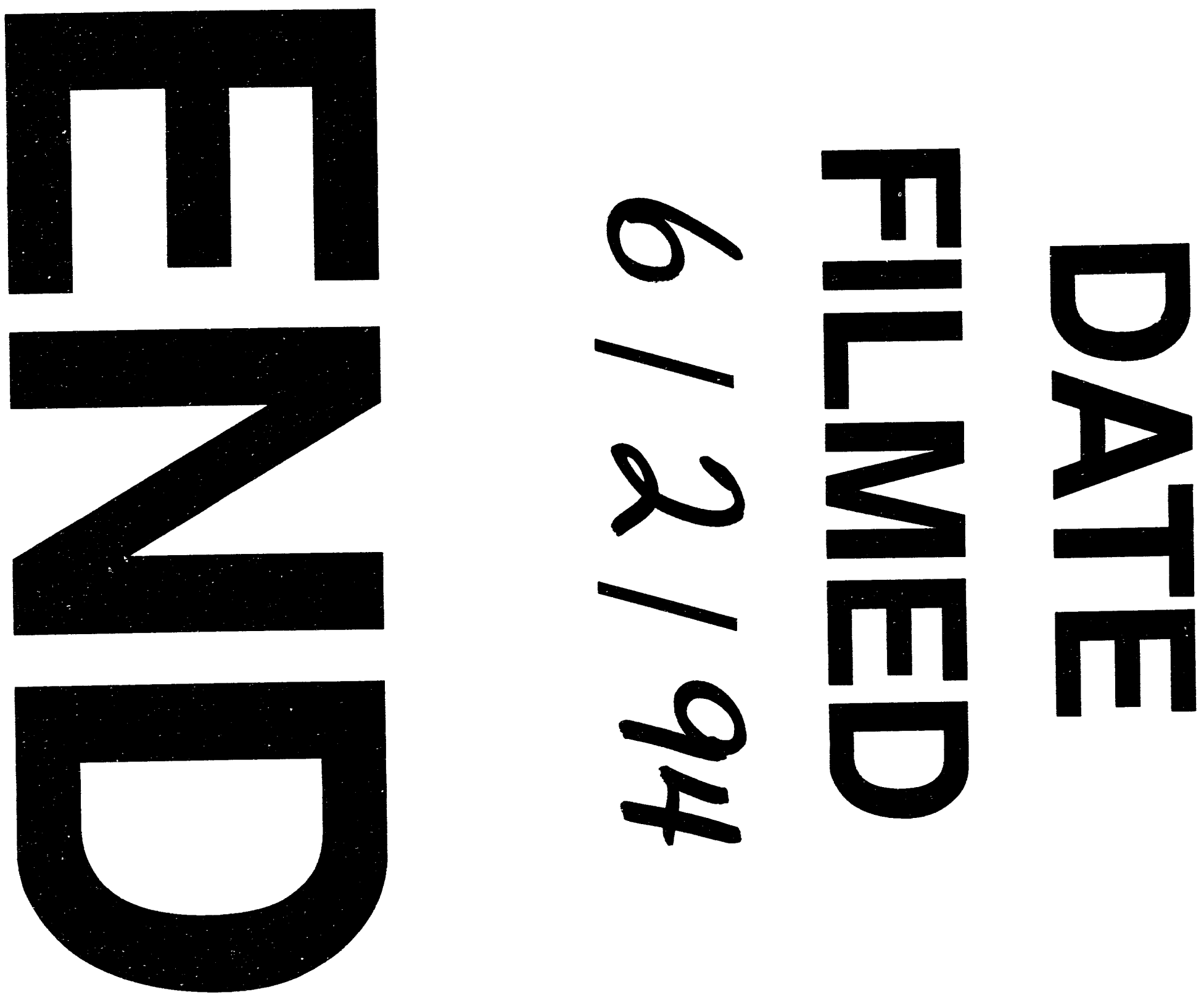

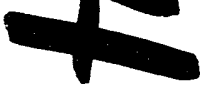


